UDC 81'255.2

DOI https://doi.org/10.32838/2710-4656/2021.3-2/03

Dmytruk L. A.

Donetsk National University of Economics and Trade

named after Mykhailo Tugan-Baranovsky

\title{
PECULIARITIES OF METAPHOR RENDERING IN THE PROCESS OF LITERARY TRANSLATION
}

The article defines the notion of metaphor, its features, points out its main functions (nominative, aesthetic, emotional and evaluative) and approaches to metaphors classifications and ways of translation. The author analyses in detail ways of rendering metaphorical figures of the novel "Tender is the Night" by F. S. Fitzgerald into Ukrainian and transformations applied by the M. Pinchevskyi to preserve the expressiveness and emotionality of the utterance.

In the course of scientific research about 250 metaphors were selected and classified, and methods of their rendering into the Ukrainian language used by the translator were pointed out and studied. It is stated, that like most authors of fiction, F. Fitzgerald, trying to fill his language with expressiveness and originality, uses metaphors of various types. Metaphorical descriptions are the most widespread.

In terms of translation, the metaphors of the novel are the most often rendered in the Ukrainian language using the traditional equivalent, less often - through substitution, explication, and omission.

The analysis of the translation of the novel revealed a tendency to simplify the translation of metaphors: replacement with partial loss of the content laid down by the author or their omission in those cases when the translator could not find a proper equivalent of the author's metaphor in the native language. Many examples of metaphorical translation of neutral expressions have also been singled out.

The author of the article proves that when translating, the author of the translation often has to choose from two equally necessary qualities for translation the most important from their point of view one. On the one hand, it is a necessity dictated by the unity of the form and content of the English metaphorical expression; and on the other hand, it is freedom dictated by the rules of the Ukrainian language and full awareness of image, laid down in the original text, the freedom of deviations from the norms of the language. The translator must combine these contradictory requirements and achieve such compliance of the necessary and sufficient, in which the success of the translation is inherent.

Key words: expressiveness, figurative units of language, literary translation, metaphor, stylistic means, transformation, way of translation.

Problem statement. Literary translation is one of the most difficult types of translation practice. This type of translation must be done in such way that the atmosphere of the original story, the style of the author is preserved in full. The translator is faced with the task of making the text interesting, preserving the stylistics, conveying the idea, thoughts and feelings of the author of the original by transforming its images into the material of another language, as well as reproducing the picture of the world built-up in the work by the author [5].

It is metaphor that allows to reproduce such a picture of the world, and therefore, an adequate literary translation of metaphorical images of the original work acquires great importance.

Actual scientific researches and issues analysis. Translation of stylistic means is a rather complex and multifaceted process. It is not just a replacement of words from one part of the speech into another, translation is a psychological, literary, ethnographic and other aspect of human activity, and it also reflects the history of translation practice of a particular country. Therefore, this theme is still one of the most discussed and interesting among scientists. It was studied by such linguists as T. Arbekova, I. Arnold, L. Barkhudarov, L. Breeva, V. Vinogradov, I. Galperin, R. Ginzburg, B. Karaban, V. Komissarov, I. Korunets, M. Kocherhan, M. Krongauz, V. Prozorov K. Chukovsky et al.

D. Diuryshyn, V. Koptilov, A. Popovych, V. Rossels and others dealt with the problems of fiction text translation.

But many problems associated with metaphor remain unresolved. For example, there is no single approach to its understanding. The translation of a metaphor requires the solution of a number of linguistic, literary, cultural and other problems.

The relevance of the study is determined by the importance of the metaphor translation aspect for 
translation studies, as well as a comprehensive approach to determining the degree of adequacy of translation of metaphorical images of the source text.

The purpose of the study is to set limits of adequacy of rendering metaphorical images of F. S. Fitzgerald's fiction into Ukrainian.

Presentation of basic results of the research. In various styles of language, especially in the styles of fiction, language tools that enhance the effectiveness of expression due to the fact that its logical content is extended by various expressive and emotional shades, are widely used.

The language of fiction differs from all other forms of speech first of all that it performs an aesthetic function. The implementation of this function is a representation of the reality in figurative, concrete-sensual form.

Enhancing the expressiveness of speech is achieved by various means, and in the first place using tropes, the so-called lexical means of imagery creating. One of the most common types of tropes is a metaphor.

Metaphor as a linguistic and speech phenomenon, of course, is of great theoretical and practical interest. The study of the nature of metaphorical transference, the analysis of the multiple new linguistic shifts that it causes, the consideration of the dependence of metaphor on its syntagmatic and paradigmatic connections helps to penetrate into a complex system of lexis, to see hidden in it the limitless possibilities of the formation of new lexical units, to reveal the dynamics of semantic relations within the lexical system of a given synchronous shift.

Metaphor has always been the focus of linguists. Theoretical interest in its study has grown over the past decades and, according to N. Arutiunova, "is associated with the widespread use of metaphor in various types of discourse" [1].

Metaphor has no unanimous definition. In the practical study of metaphor as a stylistic phenomenon, it is advisable to rely on the fact that it is based on the ratio of objective logical meaning and contextual meaning; it contains a "hidden comparison that is carried out by applying the name of one subject to another and reveals a certain important feature of another one" [1].

Based on the above, we can try to give a working definition of metaphor as a structural-semantic unity. Metaphor is a synthesis based on the similarity of the two or more objects of observation into a single dominant image, which is expressed in language with a self-contained, internally balanced structural unit.

L. Yefimov [2] points to the following most evident features of the metaphor: a) tendency to phraseologization;

b) nominativeness, which is realized in the presence of an element with a nominative value, which always acts as a decisive one in determining the semantic content of the group;

c) the allocation of the contextual group as a lexical category gives impetus to new perspectives in lexicographic work.

In the sentence metaphor (according to L. Yefimov [2]) performs the following functions:

- nominative (concretizing, generalizing, illustrative);

- aesthetic;

- emotional and evaluative.

Metaphor does not go beyond specific vocabulary; it is used mainly for nominative purposes. It nominatively serves as a technique for the formation of names of objects (stem of wineglass, eye of a needle, etc.). Through this function, the metaphor becomes a peculiar tool of reality cognition. We can also talk about the expressive functions of the metaphor, supported by the expressive qualities of the language itself, i. e a special expressive force of language units, in particular words and phrases with metaphorical meaning.

The next function that we highlight is the aesthetic function of metaphors, performing which linguistic units must most fully correspond to their purpose or individual ideal.

And finally, the third function is emotional and evaluative, which in conjunction with the two previous ones linguists stand out in a separate class of pragmatic functions of figurative units of language, and in this case metaphors.

Thus, when translating metaphors or words and free phrases with metaphorical meaning from one language into another, the linguist must be guided by the multidimensionality of figurative information due to the multifunctionality of figurative units of language, in particular metaphors.

Therefore, we are turning to the issue of the metaphor rendering aspects in the translation process.

V. Karaban suggests the following ways of translating metaphors [4]:

1) full translation, which is applied to metaphorical units in the case if in the source language and the target language both the privileges of connection and the tradition of expressing emotionally evaluative information, which this metaphor carries, coincide;

2) explication/omission is used in cases where the degree of the assumption of similarities between the source language and the target language is different, and requires either an explication of the content 
that is assumed in the source text (explication), or vice versa, the implications of the words in source text (omission);

3) substitution is used in cases of lexical or associative discrepancy between elements of metaphor in the source language and the target language;

4) structural adjustment is used in case of differences in grammatical traditional organization of a metaphor in the source language and the target language;

5) the traditional equivalent is applied to metaphors of folklore origin, biblical, ancient, when the source language and the target language have developed different ways of expressing the metaphorical similarities;

6) the parallel name of the metaphorical basis is used while translating texts based on a extended metaphor, when replacement or structural adjustment of the original metaphor is required by interlingual terms, and as for the nature of the information that is rendered, the original image must be preserved.

The main problems with translation arise when the translator tries to find a perfect equivalent of a metaphor. Faced with the author's metaphor, the majority of translators advocate fidelity to the author's text, but recognize the possibility of maneuvering when it is required by linguistic or artistic necessity. They try to see through the lines together with the author as if through his eyes, and to convey what is seen with correctly selected means of their language. They are not satisfied with dragging all the words of the original into the translation without analysis, without taking into account their functions in different languages. They try to find appropriate artistic images in their language.

In the course of scientific research we analyzed the novel "Tender is the Night" by F. S. Fitzgerald [8] in the original language and translated into Ukrainian by M. Pinchevskyi [7]. About 250 metaphors were selected and classified, and methods of their rendering into the Ukrainian language used by the translator were pointed out and studied. Like most authors of fiction, F. Fitzgerald, trying to fill his language with expressiveness and originality, uses metaphors of various types. Metaphorical descriptions are the most widespread.

In terms of translation, the metaphors of the novel are easily rendered in the Ukrainian language using the classical methods offered by T. Kazakova [3]. Thus, most metaphors are translated by the traditional equivalent, less often - through substitution, explication, omission.

The analysis of the translation of the novel revealed a tendency to simplify the translation of metaphors: replacement with partial loss of the content laid down by the author, or their omission in those cases when the translator could not find a proper equivalent of the author's metaphor in the native language.

Many examples of metaphorical translation of neutral expressions have also been singled out.

Let's analyze in more detail ways of rendering metaphors of the novel in Ukrainian and transformations applied by the translator to preserve the expressiveness and emotionality of the utterance.

... pulled in behind it a strand from the outer, darker sea [8]. - ... тялнучи за собою шлейр темнішої води з відкритого моря [7].

To translate the metaphor pulled a strand, a substitution тягнучи шлейф is used, which gives the expression more figurality.

... the cloud floated off into the vast hot sky [8]. ... але хмара відлетіла в безмежжя розпеченого неба [7].

The metaphor cloud floated off is rendered by its full equivalent хмара відлетіла, and to translate the metaphor hot sky a more expressive replacement розпеченого is applied.

... she lived in the bright blue worlds of his eyes [8]. - ... й довірливо занурилася в яскраво-синій світ його очей [7].

The metaphor worlds of his eyes is translated by the full equivalent світ його очей, while the neutral word lived is translated by the metaphor занурилася.

In the next example When they were installed on the ground floor ... [8] - ... подорожні влаштувалися в номері на першому поверсі [7] the word installed is used in an unusual connotation for a person, so when translating the translator avoids the author's metaphor and renders it with a neutral option влаштувалися.

... she had made her hard [8] - .. виховати в ній тверду вдачу [7].

The metaphor made her hard is explicated as тверду вдачу.

Now, many bungalows cluster near it [8]. Нині багато літніх котеджів тулиться навколо готелю [7].

The metaphor cluster is reproduced by its full equivalent, but at the same time the author of the translation uses the technique of explication [6] and thus creates another metaphor, which is not in the text of the original, for a more evaluative shade: літніх котеджів.

... her cheerful stoicism had each time deepened [8]. - ... виробила в собі життєрадісний стоїиизм [7].

The metaphor cheerful stoicism is conveyed by the traditional equivalent of життєрадісний 
стоїиизм, and the metaphor deepened required a substitution - виробила.

In the following examples metaphors are rendered by their full equivalents:

... she was protected by a double sheath [8]. - ... вона була захищена подвійним панциром [7].

... saw the world through her eyes [8]. - ... дивилася на світ ії очима [7].

... she were spiritually weaned [8]. - ... час уже відлучити ї̈ від грудей [7].

In the next phrase ... where pines give way to dusty poplars [8] - ... де запорошені тополі наступають на пініі [7] in order to translate the metaphor give way the author of the translation uses another metaphor наступають, which is traditional for the Ukrainian language.

After lunch they were both overwhelmed by the sudden flatness [8]. - Після ленчу їх раптом охопило тоскне заціпеніння [7].

To convey two metaphors, a restructuring of the structure is applied, as well as the substitution overwhelmed - охопило, and the traditional equivalent sudden flatness - тоскне заиіпеніння.

... between the gaiety of last winter and next winter, while up north the true world thundered by [8]. ... між веселощами минулої зими й наступноїтут, а не на півночі, де иієї пори вирує справжне життя [7].

The metaphor thundered is reproduced by the traditional equivalent вupye, and similarly the metaphor true world - справжне життя.

... his voice promised that he would take care of her [68]. - ... голос його обіияв дружбу й заступниитво [7].

The metaphorical expression voice promised is translated by its full equivalent голос його обіияв.

He had spoken out of the side of his mouth, as if he hoped his words would reach Mrs. McKisco [8]. - Слова він промовляв кутиком рота, наче сподіваючись, що вони долинуть до місіс Маккіско не зразу [7].

The metaphor words would reach is conveyed by replacing one of the components долинуть, which made the expression more emotional.

The mother's face was of a fading prettiness that would soon be patted with broken veins [8]. Обличчя матері ще зберігало прив'ялу вроду, щзо мала незабаром зовсім зникнути під мереживом синіх прожилок [7].

The metaphor a fading prettiness is rendered by its full equivalent прив'ялу вроду, and the metaphor broken veins is translated as a neutral expression. Thus, the author applys the implication and from a stylistic point of view - the transformation of logization (loss of expressiveness) [6].

Then the silence was broken by a voice in front of Rosemary [8]. - Потім просто перед Розмері залунав, розколовши тишу, чийсь гучний голос [7].

To convey the metaphor silence was broken, a reconstruction of the sentence structure is used and a full equivalent розколовши тишу.

His eyes were of a bright, hard blue [8]. - Oui сяяли сталевою блакиттю [7].

To translate the metaphor hard blue, substitution сталевою блакиттю and concretization of meaning is applied.

... she was almost eighteen, nearly complete [8]... їй було майже вісімнадиять, і вона вже, власне, розквітла [7].

The word complete in this sentence is used in an unusual connotation for a person, but in the translation a more traditional option розквітла is used, which softens the expression and gives it more expressiveness (transformation of expression) [6].

As sea and sky appeared below them in a thin, hot line ... [8] - Коли внизу відкрилися море і небо, злиті в одну вузьку смужкку ... [7].

The word appeared is used in a metaphorical sense, but it is less expressive than the Ukrainian equivalent відкрилися, in relation to the noun it characterizes. Therefore, it is possible to state the use of the technique of substitution and transformation of expressivation [6]. Another metaphor hot line is translated as a neutral expression, which indicates the implication technique.

... not from the necessity of stimulating jaded nerves [6] - ... щоб дати лад розхитаним нервам [7].

The metaphor jaded nerves is rendered not by its full equivalent, which is not widely used in Ukrainian, but by its traditional equivalent розхитаним нервам. At the same time, the non-metaphorical word stimulating is translated by a figurative unit дати лад, which, on the one hand, partially changes the meaning, and on the other - gives emotive shade to the expression.

Conclusions. Thus, there is no doubt that the translation of literary texts is the most complex and unique of all types of translation. It is in literary texts that the expressive means of language are presented in the whole spectrum: comparisons, allegories, metaphors, oxymorons, and so on. After all the language of fiction is particularly imaginative.

Research of the methods used by the translator to render metaphors into Ukrainian and comparing them with those described in the linguistic literature, clearly demonstrates the lack of a certain universal 
model of translation that can solve all the problems that the translator faces.

It is obvious that in each case the translator is not faced the task to choose from several ready-made options, but the need to find a way out of the language situation creatively with the least loss in terms of preserving the style and content of the original.

When translating, the author of the translation often has to choose from two equally necessary qualities for translation the most important from their point of view one. On the one hand, it is a necessity dictated by the unity of the form and content of the English metaphorical expression (let us call it accuracy); and on the other hand, it is freedom dictated by the rules of the Ukrainian language and full aware- ness of image, laid down in the original text, the freedom of deviations from the norms of the language.

The translator must, based on the circumstances, combine these contradictory requirements and achieve such compliance of the necessary and sufficient, in which the success of the translation is inherent. However, these requirements are not mutually exclusive phenomena. In the living translation process, on the contrary, they complement each other. In the conflict between the need dictated by the original, and the freedom represented by the rules and capabilities of the native language, the obligatory approximation to the original is the degree of freedom, and the admissibility of choosing the best, most appropriate means of the Ukrainian language is the degree of accuracy.

\section{References:}

1. Арутюнова Н. Д. Функциональные типы языковой метафоры. Известия Академии наук. Серия «Литературоведение, Языкознание». 1978. Т. 37. № 4. С. 87-160.

2. Єфімов Л. П. Стилістика англійської мови і дискурсивний аналіз : навчально-методичний посібник. Вінниця : Нова книга, 2004. 240 с.

3. Казакова Т. А. Теория перевода (лингвистические аспекты). Санкт-Петербург : Союз, 2003. 296 с.

4. Карабан В. І. Переклад англійської наукової і технічної літератури. Граматичні труднощі, лексичні, термінологічні та жанрово-стилістичні проблеми. Вінниця : Нова книга, 2004. 276 с.

5. Кухаренко В. А. Интерпретация текста : учебник для студентов филологических специальностей. Одесса : Латстар, 2002. 292 с.

6. Науменко Л. П., Гордєєва А. Й. Практичний курс перекладу з англійської мови на українську : навчальний посібник. Вінниця : Нова книга, 2011. 136 с.

7. Фіцджеральд Ф. С. Ніч лагідна. URL: https://www.ukrlib.com.ua/world/printit.php?tid=1166.

8. Scott Fitzgerald F. Tender is the Night. URL: https://litportal.ru/avtory/frensis-skott-ficdzherald/read/page/3/ kniga-tender-is-the-night-noch-nezhna-kniga-dlya-chteniya-na-angliyskom-yazyke-1033830.html.

\section{ДМИТРУК Л. А. ОСОБЛИВОСТІ ПЕРЕДАЧІ МЕТАФОРИ У ПРОЦЕСІ ПЕРЕКЛАДУ ХУДОЖНЬОГО ТВОРУ УКРАЇНСЬКОЮ МОВОЮ}

Стаття визначає поняття метафори, ї̈ особливості, вказує на основні функиії (номінативну, естетичну, емоційну та оцінну) і підходи до класифікаиії метафор та способів їх перекладу. Автор детально аналізує способи відтворення метафоричних фігур роману «Ніч лагідна» Ф. С. Фіцджеральда українською мовою, а також трансформації, застосовані М. Пінчевським для збереження виразності й емоиійності висловлювання.

У ході наукової розвідки було відібрано та класифіковано близько 250 метафор, вивчено методи їх перекладуукраїнськоюмовою, щзовикористовуютьсяперекладачем. Зазначається, що, якібільшість авторів художньої літератури, Ф. С. Фіиджеральд намагався надати своїи мові виразності й оригінальності, а тому використовував метафори різних типів. Найпоширенішими є метафоричні описи.

3 позииії перекладу метафори роману найчастіше передаються украйнською мовою традииійним еквівалентом, рідше - иляхом заміни, додавання та вилучення.

Аналіз перекладу роману виявив тенденцію до спрощення перекладу метафор, а саме до заміни із частковою втратою змісту, встановленого автором, або їх вилучення в тих випадках, коли перекладач не зміг знайти належний еквівалент метафори автора в рідній мові. Також було виділено багато прикладів метафоричного перекладу нейтральних висловів.

Автор статті доводить, щзо під час перекладу перекладачеві часто доводиться вибирати з двох однаково необхідних якостей перекладу одну, на його думку, найважливішу. 3 одного боку, це необхідність, що продиктована єдністю форми та змісту англійського метафоричного вислову, а з інщого - ие свобода, продиктована правилами української мови, і повне усвідомлення образу, закладеного в оригінальному тексті, свобода відхилень від норм мови. Перекладач повинен поєднати иі суперечливі вимоги та досягти такої відповідності необхідного й достатнього, за якої успіх перекладу буде безперечним.

Ключові слова: виразність, образні одиниці мови, художній переклад, метафора, стилістичні засоби, трансформачія, спосіб перекладу. 